\title{
Promising Speech Act by the Tenth Year Students of SMAN STAR I Tahunan Jepara
}

\author{
Ahmad Mubais \\ Politeknik Balekambang, Indonesia
}

\begin{abstract}
The purpose of this study is to analyze pragmatic study that focuses on promising speech act delivered by Tenth Year Students of SMAN STAR 1 Tahunan Jepara. This study concentrates on analyzing the promising speech act actualized by the students, the factors that influence the students in actualizing promising speech act, how the factors influence students to deliver a promise and what dominant strategy used by the students. This research is qualitative descriptive research and the source data is document. There are two methods used to collect the data; Role play and DCT (Discourse Completion Tasks) methods. The types in analyzing the data are transcribing, coding, classifying and interpreting. The subjects of the research are 22 Tenth Year Students of SMAN STAR 1 Tahunan Jepara at sixth and eighth semester. There are 528 utterances of promising speech act that actualized by the students from the Role play and DCT data elicited. Based on the analysis, the study reveals some strategies used by the students; future action, promise-to-act and predictive assertion strategy to actualize the promise. The probable factors that influence students in actualizing the promise are distance, dominance and imposition. However, those factors (distance, dominance and imposition) are not fundamental factors that impose the students in actualizing the promise. The different combination of social parameters in some situation or circumstances delivers different strategy for students to deliver promising speech act. The different combination of the three factors in situation given, interference of students' native language, and pragmatic transfer in the language learning process also affects students to actualize a promise strategy. The result of this study shows that the future action strategy is the dominant strategy used by the students.
\end{abstract}

Keywords: DCT, promising speech act, role play, students

\section{INTRODUCTION}

Language is a system of arbitrary conventionalized vocal, written or gestural symbols that enable members of a given community to communicate intelligibly with one another (Brown, 2000, p.5). It is a way as a communication tool among human beings in this world. Language uses systematic patterns in many forms and it may not be stable by the era. The forms of languages extend to what are now so-called spoken and written languages. By the languages people express their ideas, thoughts, knowledge, and feelings. One of primary functions of languages is the expression of personal identity (Crystal, 2003). Students and learners from many countries have many problems in learning English especially English as a foreign language. Even though, according to Robert A. Day (2011) that English really is simple, but it contains massive vocabulary of some half-million words. Therefore, with the massive vocabulary it can be used to describe both thoughts and things with exquisite precision. Many students have not had the opportunity to learn how to express thinking skills in English because they are continually exposed to curriculum that 
focuses on basic skills in English (Sofwan, 2015).

In order to be able to understand each other in communication, people have to know the language itself that is integrated on four skills of language: reading, listening, writing and speaking. How well we can communicate to others depends on how we hold all language skills. Warsono (2017) said that understanding the context of situation in a text, particularly spoken, students are exposed to conversation texts that mostly focus on the use of functional expressions. The requirement to be able to understand each other in a worldwide range is what brings people to use English as the International Language.

Ellis $(1994 ; 13)$ said that communicative competence includes knowledge the speakerhearer has of what constitutes appropriate as well as correct language behavior in relation to particular communicative goals. In a case of asking questions, for example, the speaker must know how to set a question correctly and to whom the question is addressed. We may say that different interlocutor requires different way. It is what Ellis means that the purpose of communicative goals influenced the way we use language to communicate. It requires different way and strategy how to ask question to a professor or a lecturer in a classroom to a new one that we meet on a particular place. Furthermore, the same situation takes place not only in asking a question, but also in promising, inviting someone, answering a question, making a request, offering something, and many others.

Mey (1993), quoting Searle says that a promise should not be about things that are going to happen, or should happen anyway. Promise is one of the speech acts that deal with something that may happen in the future and commitment of the speaker. It gives a clarity that someone cannot promise that the sun will raise tomorrow because it does not deal with commitment of the speaker, or in this case we call the speaker as promisor.

In Pragmatics field, as a performative act promise cannot be judged as true or false: they would rather be considered as felicitous or infelicitous (Austin, 1962). Lyon (1977) stated that Performative act of promise is under the speech act theory as an act performed in saying something. In daily life, it is very familiar for some people in actualizing promises. Sometimes, promises are made with no intention of keeping them. As an example, when people say "I'll pick you later soon, and I'll be there in ten minutes", they have made promises though those promises are not kept. How could promises be actualize without intention to keep them? It can be withdraw due to the fact that not all promises are felicitous. In actualizing promises, some people may be felicitous that they intend to keep the promises, but it can be different for some others. They may not have any intention to keep the promise. There are some felicity conditions to determine whether a certain promise is felicitous or infelicitous. Based on these conditions, we are able to discover whether a promise is made as a merely lip service or a real felicitous promise. Furthermore, pragmatic competence is one of communicative competences that has important role in determining the language purpose to use appropriately in order to achieve the goals of communication.

The ability of communicative competence is a kind of requirement to communicate with others. Some of communicative competence covers discourse competence, pragmatic competence, linguistic competence, socio cultural competence and actional competence. In order to fill the gap among the speakers, especially Indonesian students in the level of tenth year students that English is as a foreign language or second language, pragmatic competence is such a communicative competence which is important to study.

As stated by Mujiyanto (2017) that learning a second language, learners cannot totally disconnect themselves from their cultural context where they rely on the knowledge source constructed from their home society. Communicative competence among the speakers is 
important because the second language students have the problem with the interference of their native language. For long time and many years, exploring the relationships between cultural identity and language development has existed in second language acquisition researches. Those, the gaps among the speakers of different languages can be decreased by the study of speech act in various languages and perspectives.

This study focus on the analysis of promising speech act as a pragmatic field that actualized by the tenth year students of SMAN STAR 1 Tahunan Jepara. The objectives of the study are concentrates on analyzing the actualization of promising speech act by the students, the feasible factors that influence the students in realizing promising speech act, what dominant strategy used by the students and how those factors influence students to actualize a promise.

Theoretically, the research is expected to enrich the previous theories of speech act of promising since this research will give description of how tenth year students produce promises in their daily life. Practically, it is hoped that the research will give contributions to students who study English and English teachers or researchers to develop further research related to speech act of promising strategies. Finally, the research can be used as supplementary information for both English as a foreign language or English as a second language teachers and learners related to speech act of promising strategies. In line with the previous statement, the finding will give a contribution to the readers to enrich the knowledge specifically about promising speech acts. It also can be useful in cultural understanding in learning English based on the native speaker's intention in expressing speech act of a promise in daily activities and develop the awareness of language varieties which may result in better understanding of others' utterances to achieve the goals of communication.

Some previous studies about promising speech acts have been analyzed by the researchers. Saeidi et al (2014) conducted a research on speech act of promising. The research compared speech act of promising that actualized and recognized by native speakers and Iranian English Foreign Language learners. The gap in communicative competence between speakers is the basis of this study. The study focused on investigating the strategies used in expressing promises in different situations. The data were not only expression of promising in English but also promising expressions in Farsi, the Iranian language. It used an open-ended data collection technique to study participants' responses and verbal reactions in the different situations. The result revealed that the two groups vary in using strategies and types of promising speech act. The result showed that inappropriateness expressions and strategies that they have actualized in their English responses have been affected by the sensitivity of their first language.

The research conducted by Bernicot and Laval (2004) on children about promising speech has two objectives. The first was to gain an accurate and precise understanding of the role of the preparatory condition in the comprehension of promises. The second objective was to test linguistic forms which do not contain the verb promise but which, according to the speech acts classification (Searle and Vandeveken, 1985; Vanderveken 1990a; 1990b) are specifically commissive, i.e., they contain verbs in the future tense (active or passive voice). This current research makes the different from Benicot and Laval's research in terms of the subject of the research. The subject of the previous study is children, and the current research is tenth year students of SMAN STAR 1 Tahunan Jepara.

Suwigno (2011) studied the interlanguage pragmatics of agreement strategies by non-native speakers. The research took two groups of Indonesian respondents who are college students in the sixth semester who were given questionnaire in the form of DCT (Discourse Completion Task). It showed that disagreement is actualized through contradiction, counterclaim, 
irrelevancy claim, contradiction and counterclaim, and challenges to personal/non-personal issues in different social status. However, both Suwigno's research and this current research used DCT, by using two methods of collecting the data the bias is avoided in this current research. Those methods are the role play and DCT.

Schauer \& Adolphs (2006) also explored the similarities and the differences between a discourse completion tasks (DCT), corpus data and discussed potential implications for using the two in pedagogic context. Five million word corpus of spoken English found in that study by contrasting native speakers' expressions of gratitude elicited by the DCT. They also examined the advantages and disadvantages of the both data sets with regard to the language-teaching context. The result showed that a combined use of both instruments might aid the teaching of formulaic sequences in the classroom. This particular study compared the DCT result with corpus data. Meanwhile, this current research used both DCT and role play to avoid the bias and to produce a balance result.

The study also conducted by Karyono (2015) about the promising speech act used by teacher of Vocational School in Pacitan that focused on pragmatic analysis of the speech act of promising used by Pacitan Vocational English teacher and the aimed of the study is to fulfill the gap of the dissimilar languages and culture with interethnic communication difficulties. The study focused on the analysis of the strategies of promising speech act and the dominant strategy used by Pacitan Vocational English teachers. The data of the study is documents. The documents are taken from Vocational English teachers which consist of 15 females and 10 males and the level of English proficiency was middle to advance. The data were collected from the responses of DCT produced by the teachers. He found that the respondents applied nonperformative and performative verb in stating the promises. The dominant promising strategy used by the teachers is promising non- performative verb strategy.

This current study has the similarities and differences to all of the previous studies. The similarity is that all of the previous studies and this research analyze the promising speech acts utterances. Furthermore, there are also differences between each research. Some of the differences of each research have been explained above. Almost all of the previous studies compared the use of speech act by native speakers of English or English as a second language. Most of the previous studies also only analyze realization and strategies of promising speech act. In this current study, the researcher will examine the actualization and the strategies of promising speech act and also the factors that affect the strategies of promising speech act by tenth year students of SMAN STAR 1 Tahunan Jepara.

\section{METHODS}

The present study belongs to descriptive qualitative research. The subjects of this study were the Tenth Year Students of SMAN STAR 1 Tahunan Jepara that consists of 22 students. The students were chosen by the assumption that they used English as a means of communication. The object of the study was utterances of promising speech act actualized by these students. The data source of this study is document. The documents are taken from Tenth Year Students of SMAN STAR 1 Tahunan Jepara. The study deals with expressions of promises actualized by Tenth Year Students of SMAN STAR 1 Tahunan Jepara consist of ten male and twelve female students. All students are from the second semester of science major. The data was taken from responses of DCT and Role Play that was produced by the students.

There are two instruments that are used in this study to collect the data; DCT (Discourse Completion Task) and Role Play. DCT is the most effective research instrument (Seran\&Sibel, 
1997). DCT has been commonly applied as one of the methods to collect the data with second language learners as the contributors. DCT includes a brief description of the situation and a one participant dialogue. Through a controlled elicitation method called an open questionnaire which is a modified version of DCT to collect data in the following study. Each situation consists of a brief description of the addressee's characteristics important to this study, namely, social distance (the relative degree of the social power of the interlocutors over each other), and finally the offence being committed (Afghari\&Kafiani, 2005).

Table 1. Questionnaire Instrument of PSA (Promising Speech Act):

\section{PSA Awareness and DCT PreTest}

Questions Answers (Choices)

Q1. Which statement is true related to promising - Promise deals with speaker's intention and speech act theory? commitment regarding things that will happen in the future.

- Promise is not deals with speaker's intention and commitment regarding things that will happen in the future.

22. Which utterance that is belongs to a promise? "I promise that the sun will raise tomorrow".

- "I will marry you next year".

Q3. Which of these following utterances does not "I bet you that the world is round". belong to a promise?

" "I will pick you up at 07.30".

51. Yours best friend calls you on the phone. S/he ' Your best friend: "Hi, I want to borrow your wants to borrow your book, but $\mathrm{S} / \mathrm{he}$ is sick. S/he needs precious reference with his/her assignment. You promise him/her that you will go to his/her house to bring the book. book. I need it for my assignment, but I cannot go to your house to pick it because I'm sick now. Do you mind if you bring it to me here?"

- Response: "Oh, I'm sorry to hear that. I hope you will get better soon. Don't worry, I promise I will come to you to give the book".

52. Your girlfriend will have a birthday next week. " Your girlfriend: "I want a special present for my She asks you for a special present. You promise birthday! I hope I get a new satchel, this one is that you will buy her a new branded satchel old-fashioned".

because her bag is old-fashioned. - Response: "Well, honey. I'll give you a special present as you want".

53. You find a young boy got an accident and 'A young boy: "Help me please, I've got an bleeding in a street but it seems not badly wound. accident".

He needs help, but nobody was around to help but - Response: "Okay, just a moment. I'll be back to you. You are in a hurry for something and you help you. Just stay here for a while, Okay? promise that you will be back soon.

S4. In the campus corridor, one of your friends, - Your friend : "Hi, are you Ricky? I'm Tia. although you don't know his name, suddenly asks your help for his project to make a computer programming system. You promise that you will help him. Maybe you don't know me. I'm from the 5th semester of Accounting Department. My friend said that you are capable in programming computer system including about accounting too. I need your help to complete my project. Would you like to help me?"

- Response: "Yes, I'm Ricky. I'm sorry; I'm very busy right now. But, don't worry; I will help you when I'm free". 
S5. Your younger brother (7 years old) is - Your younger brother : "What are you doing? naughty. He always makes a noise and asks you a What are you studying? question while you are studying. You promise - Response: "Keep quiet. I'm studying now and I him that you will give him a lollipop if he keeps quiet. have to focus with this. I promise if you can keep quiet and not make an idle chit chat with me I'll give you a Lollipop. Okay?"

S6. You have a 5-years-old daughter. She wants - Your daughter : "Mom, I want that Barbie doll! you to buy her a new Barbie Doll. The Barbie Please Mom? That is pretty, please? My old Doll is very expensive and you don't bring Barbie needs a friend. Mommy, Please?"

enough money. You promise her that you will - Response: "No, Honey. I don't have much money buy it for her next month. to buy those lovely Barbie. We will come back here next month, Okay?"

S7. You are going home late. Your father - Your father : "Where have you been? What supposed that you should help him to prepare for time is it? You should be at home three hours ago. something. So, your father gets mad to you Youknow?"

because you come home late. You promise him - Response: "Sorry for being late, Dad. My friend that you will not do it next time. asked me to come to his house. Next, I will make sure not to go home late again".

S8. Your mother is a very busy. She is business - Your mother : "I'm going to work now. Help women. Before she goes to work she asks you to me with the chores, OK? Will you help me wash wash the dishes and cook for dinner. You promise the dishes and cook for dinner, honey?" her that you will do it.

Response: "Yes, Mom. Don't worry. It's my pleasure to help you".

S9. In a restaurant, a waiter comes for you to take - Waiter: "Excuse me, Sir. May I take your order?" your order. But you are still waiting for a friend. - Response: "Hmmm...., wait a minute. I have to You promise to the waiter that you will call him wait my colleague. I'll call you later when when you are ready to order something. everything is ready to order, Okay?

S10. Tony is a friend of your brother, Ryan. He - Tony: "Your brother broke my toy! He's your tells that his car (a toy) is broken by your 7-years brother, I think, you should pay for this!"

old brother (Ryan). Tony says that you are - Response: "Yeah, I know. I will responsible for responsible for your brother's mistake. You tell that and I think I have to buy a new one for you". Tony that you promise to buy him a new one.

S11. You are in a classroom. You forget to bring - Lecture: "Is there any problem with your paper? your paper to be submitted. All of your friends are Why don't you submit it right now?"

ready to submit their paper. And when your - Response: "I'm so sorry, Sir. My Paper is left lecturer asks you to submit your paper, you look so nervous and tells that it still left behind in a house. So, you promise that you will bring your paper tomorrow on his desk.

\begin{tabular}{|c|c|}
\hline $\begin{array}{l}\text { S12. Your new boss doesn't like food you order } \\
\text { in one of restaurant near the office. He complains } \\
\text { about it because of the taste is not good and he } \\
\text { tells you that he needs another food from another } \\
\text { restaurant for lunch tomorrow. You promise that } \\
\text { you will order him a food from his favorite } \\
\text { restaurant tomorrow. }\end{array}$ & $\begin{array}{l}\text { - Your boss: "Ugh, where is it food is ordered? I } \\
\text { can't eat that kind of food. The taste is so awful. } \\
\text { It'll make me sick. I'll need another food for lunch } \\
\text { tomorrow." } \\
\text { - Response: "Sorry, Sir. I order this food in a } \\
\text { restaurant near here, one block from this office. } \\
\text { Tomorrow, I promise I will order from the other } \\
\text { restaurant. I'll make sure to make the food taste } \\
\text { good and delicious". }\end{array}$ \\
\hline
\end{tabular}
behind at home. I promise to submit it tomorrow on your desk, Sir". 
There is a pretest of PSA awareness and DCT as in the table1 shown before students completing the task of DCT as a data to collect and analyze. This test aimed to measure students' understanding about the promise. By the test students were supposed to be able in producing promising speech act by completing the DCT. Students have to answer and complete twelve of situation given before completing the DCT. The results revealed that almost all students of SMAN STAR 1 Tahunan Jepara understand the theory of promising speech act. The second instrument to collect the data is role play method. Kasper \& Rose (2002, p. 86) stated role play as a social or human activity in which participants take on and act out specified roles often within a predefined social network or situational blueprint.

There are several types I used in this study as a method of analyzing the data since; the data are in the form of qualitative data. Those types are transcribing, coding, classifying and interpreting. First, transcribing deals with the process of transcribing the sound data from the role play activity. In this process I transcribed the recording data (audio data) into written text by listening to the audio data, and typed it down in the form of word document. Since I used the DCT data, role play data and awareness test to support each other, the data that needs transcribing is only from the role play. A coding is giving code to the speech act of promising, based on the data I collected. Second, the next step is to classify. Classifying is the process to classify the data. The process of classification is conducted based on the promise strategies proposed by Bernicot and Laval (2004).

These two steps are done at the same time since I give codes (which are in the forms of numbers) and put them in different columns in the tables in order to classify it. The next classification is based on the probable factors of promising strategies. In this step, each factor has different situations that they are suited to the purpose. The coding and classification tables will be in list of the appendix. Finally, in the interpreting phase, I interpreted the data which can be seen and explained in the following chapter.

\section{RESULTS AND DISCUSSION}

Based on the results of this study explained in the previous chapter, Tenth Year Students of SMAN STAR 1 Tahunan Jepara actualized a promise by utilizing three types of strategies. Those three strategies are future action, promise-to-act and predictive assertion strategy. Futureaction strategy is a strategy of promise, which applies the verb conjugated in the future tense. The verb 'promise' does not appear, and the grammatical subject of the sentence is the person making the promise. The social act intentionally posed by the speaker is a commitment, but not a firm one.

Next, the strategy called as promise-to-act strategy is a strategy, which explicitly contains the verb 'promise' followed by a verb in the infinitive form. The grammatical subject of the sentence is the person or someone that makes the promise. The social act intentionally posed by the speaker is a firm commitment. However, the last strategy is predictive assertion strategy that is a strategy in which the verb is in the future tense and passive voice. The verb 'promise' also does not appear and the grammatical subject of the sentence is not the person making the promise. In this case, the strategy they used to actualize promise showed has no commitment on the part of the speaker. It is a prediction of something that will happen in the future related to what the speaker says to promise.

There are 528 utterances of promise produced by students as the respondent in all situations both DCT and Role play data elicited.

Here are the revealed results of promise realization from the highest strategy to the 
lowest one;

1. Future action strategy is $70.8 \%$ or 374 out of 528 realization of promise strategies.

2. Promise-to-act strategy is $22.4 \%$ or 118 out of 528 realizations or occurrences of promise strategies.

3. Predictive assertion strategy is $6.8 \%$ or 36 out of 528 realization of promise strategies.

The strategy that most frequently used by the respondents to actualized promising speech act in this study is future action strategy. It is most frequently used by the respondents because they are Indonesians' students, especially Javanese people. They tend to express a promise implicitly without using the word 'promise' itself. Although, there are some situations that have the same combination of social parameters both in DCT and Role play, the data elicited from the respondents have different dominant strategy as explained in the discussion. The percentage and frequency of all the data gathered from DCT and Role play are provided in the appendices.

There are many factors that influence the students in actualizing strategies of promise using those three strategies. Those factors are the combination of social parameter, student's ability in understanding a promise, the interference of students' native language, and pragmatic transfer in the language learning process. Distance, Dominance and Imposition are the combination of social parameters in each situation given as factors that determine students in using what strategy that will be utilized, though not of all students use the same strategy in the same condition or situation given.

Almost students employed promise- to-act strategy in the situation that designed contains Hearer Dominant, but they employed the other strategy when the combinations of social parameters turn with the different social parameters. It also happened in the situations that has the social parameter of High Imposition and the others. The combinations of each social parameter determine respondents to use the strategy to produce a promise. The ability of student's awareness about promise also takes part in students' actualization of promise. How students understand what is a promise related to the commitment obviously lead the students to utter or state a promise correctly by using the right strategy. Some students delivered promise with actually a prediction rather than commitment of promise. The study also reveals that some students delivered promise strategy in grammatical error.

The interference of students' native language and pragmatic transfer in the language learning process also affects the respondents in uttering a promise. It cause the students employed the grammatical errors in structuring or uttering a promise. By their native language, students initially actualized a promise to interpret and then translated to target language when uttering a promise. So that, it makes the utterances produced by the students are not as English native speaker produced. Students' ability in understanding the grammatical of English language determine to produce utterances of promise correctly. That is to say, the strategies that they employed are different to each other.

\section{CONCLUSION}

This study found that Tenth Year Students of SMAN STAR 1 Tahunan Jepara employed a promise by using three types of strategies; predictive assertion strategy, promise-to-act, and future action. The most frequently used strategy by students to actualize a promise is the same strategy such as future action strategy. The least frequently used by the students to actualize promise strategy is predictive assertion strategy. The interference of students' native language and pragmatic transfer in the language learning process also give an impact to Tenth Year Students of 
SMAN STAR 1 Tahunan Jepara in uttering a promise, so that the students employed the grammatical errors in structuring or uttering a promise. When uttering a promise, students actualized a promise initially used their native language and then translated to target language. It makes the utterances produced are not as English native speaker produced both grammatically and culturally. Students' ability in understanding grammatical English and less vocabulary determine to produce utterances of promise correctly. Although, this study is not focus on grammatical errors and mastering vocabularies, some finding indicated of two matters of it; grammatical errors and less vocabulary. Those factors lead the students employed different strategy in actualizing promise to each other.

Students in the level of tenth year that have studied English as a second language or as a foreign language naturally have different culture from the Native speaker, it is important to know more about English culture. The ability to convey correctly promise speech act is influenced by to what extent we know the target language is used and the ability of communicative competence in English culture. And, also many students especially at the level of senior high school program in actualizing utterances of a promise are influenced by the negative interference, so that they have many grammatically error made. By avoiding negative interference, students can ease the grammatical error. The present study will lead to the next researchers in a field of promise speech act, it is hoped that there will be a study that will reveal the promise more detail and naturally design to native speaker and non-native speaker to compare in what more strategies will they use, and also to understand the probable factors that will affect in actualizing promise speech act as the subject. Hence, it will contribute to decrease the communicative competence gap between the speaker and hearer. So that the communication will run effectively including when the speaker, in this case is students can communicate well.

\section{REFERENCES}

Afghari, A., \& Kafiani, V. Apology Speech Act Realization Paterns in Persian. Iranian Journal of Applied Linguistic (IJAL). Retrieved from http://www.sid.ir/En/VEWSSID/J pdf/8762005021.pdf]

Aliningsih, F., \& Sofwan, A. (2015). English Teachers' Perceptions and Practice of Authentic Assessment. Language Circle: Journal of Language and Literature 10(1), 19-27.

Ariff, T.A. Z., \& Mugableh A.I. (2013). Speech Act of Promising among Jordanians. International Journal of Humanities and Social Science, 13(3), 248-266.

Austin, J. L., Urmson, J. O., \& Sbisà, M. (2011). How to do things with words: The william james lectures delivered at Harvard University in 1955. Oxford [England: Clarendon Press.

Brown, P. \& Levinson. (1987). Some Universal in Language Usage. Cambridge: Cambridge University Press.

Bernicot, J., \& Virginie L. (1996). Promises in French children: comprehension and metapragmatic knowledge. Journal of Pragmatics, 25(1), 101-122.

Blanco, S. A. (January 01, 2010). Promises, threats, and the foundations of speech act theory. Pragmatics, 20, 2, 213-228.

Blum-Kulka, S. (1987). Indirectness and politeness in requests: same or different? Journal of Pragmatics, 11(2), 131-146.

Blum-Kulka, S., \& Olshtain, E. (1984). Requests and apologies: a cross cultural study of speech act realization patterns (CCSARP). Applied Linguistics, 5(3), 196-213.

Cucchiarini, C., \& Strik, H. (January 01, 2019). Second Language Learners' Spoken Discourse. 
Cutting.J. (2002). Pragmatic and Discourse: A Resource Book for Students. London: Routledge

Christiansen, M. H., Collins, C., \& Edelman, S. (2009). Language Universals. Oxford: Oxford University Press.

Ellis, R. (1985). Understanding Second Language Acquisition. Oxford: Oxford University Press.

Ellis, R. (1994). The Study of Second Language Acquisition. Oxford: Oxford University Press.

Egner, I. 2006. Intercultural Aspects of the Speech Act of Promising: Western and African Practice. Intercultural Pragmatics, 3(4), 443-464.

Geis, M L. (1995). Speech Acts and Conversational Interaction. New York: Cambridge University Press.

Hashim, Suhair S. M. (2015). Speech Acts in Political Speeches. Journal of Modern Education Review, 5, 7, 699-706.

Hsieh, C.L., \& Chen, C.Y. (2005). A Cross- Linguistic Study on the Speech Act of Refusals with Pedagogical Implications. TESOL

In Kecskés, I., \& In Assimakopoulos, S. (2017). Current issues in intercultural pragmatics.

Khalim, A., \& Warsono. (2017). The Realization of Interpersonal Meaning of Conversation Texts in Developing English Competencies and Interlanguage for Gade X. English Education Journal, 7(2), 123

Kasper, G. (1989). Interactive Procedures in Interlanguage Discourse. In W. Oleksy (Ed.), Contrastive Pragmatics (pp. 189- 229). Amsterdam: John Benjamins.

Levinson, S. C. (2013). Pragmatics. Cambridge: Cambridge University Press.

Lyons, J. (1977). Semantics. Vols., i \& ii. Cambridge: Cambridge University Press.

Lyulina, A. A., \& Scherbina, V. (2016). Speech Acts of Promise and Their Functioning in Political Discourse, 44, 165-178.

Ali, M.A., \& Mujiyanto, J. 2017. The Influence of Cultural Identities in Second Language Acquisition: A Perspective from Secondary Program(Semarang Multinational School). English Education Journal. 7 (1), 35

Martínez-flor, A., \& Usó-juan, E. (n.d.). Estudiosdelingüísticainglesaaplicada, 47-87.

Mey, J. L. (1993). Pragmatics An Introduction. Oxford: Blackwell Publishing.

Morkus, N. (2009). The Realization of the Speech Act of Refusal in Egyptian Arabic by American Learners of Arabic as a Foreign Language. University of South Florida

Nguyen, T.T.M. (2008). Criticizing in an L2: Pragmatic Strategies Used by Vietnamese EFL Learners. Intercultural Pragmatics, 5(1), 41-66.

Rahman Hz., \& Benni I. (2016). Pragmatic Transfer in the Speech Act of Promise by English Department Students of Semarang State University. Thesis. Universitas Negeri Semarang.

Richard, J.C., \& Richard W.S. (1983). Language and Communication. London: Longman

Saedi, S.N. et al. (2014). A Comparative Study of English Native Speakers and Iranian EFL Learners' Production and Recognition of the Speech Act of Promising. International Journal of Education Investigations, 1(1), 191-204.

Schneider, K. P. (n.d.). Handbooks of Pragmatics. Wolfram Bublitz.

Seely, J. (2013). Oxford Guide to Effective Writing and Speaking: How to Communicate Clearly. Oxford: OUP Oxford.

Searle, J. R. (2012). Expression and meaning: Studies in the theory of speech acts. Cambridge: Cambridge Univ. Press.

Smith, P. W. H., \& University of Leeds. (1991). Speech act theory, discourse structure and indirect speech acts. Leeds: University of Leeds 
Stoll, P. (1996). Speech Acts and Conversation: the Interactional Development of Speech Act Theory. BIBLID, 3(4), 465-475.

Syairozi, M. I. (2021). Analisis Kemiskinan di Sektor Pertanian (Studi Kasus Komoditas Padi di Kabupaten Malang). Media Ekonomi, 28(2), 113-128.

Thiselton, A. C. (2020). Promise and prayer: The biblical writings in the light of speech-act theory. Eugene, OR: Cascade Books

Thomas, J. 1995. Meaning in Interaction: an Introduction to Pragmatics. London: Longman. Group limited.

Wang, Y., \& Chen, C. D. (2014). Chinese Children's Acquisition of the Promissory Speech Act, 55-93. https://doi.org/10.6241/concentric.ling. 40.2.03

Wang, V. X. (2011). Making Requests by Chinese EFL Learners. Amsterdam/Philadelphia: John Benjamins Publishing Company.Verbs: Semantic Dictionary. New York: Academic Press.

Yule, G. (2010). Pragmatics. Oxford: Oxford Univ. Pr.

Yule, G. (2020). The study of language. 